\title{
KONSEP PENGENTASAN KEMISKINAN PERSPEKTIF ISLAM
}

\author{
Syaiful Ilmi \\ Fakultas Syariah dan Ekonomi Islam IAIN Pontianak \\ Email:syaifulilmi78@gmail.com
}

\begin{abstract}
Poverty has been haunting every individual or even country for ages. It is a classic problem that appears along with human history. In Indonesian context, UUD 1945 has declared the elimination of poverty, while Islam according to Al-Qur'an has clearly ordered the eradication of it which is mentioned in the term of al-faqîr andalmiskin. But, in fact, there is a paradox between the mission and reality. Therefore, this writing intends to map the concept of poverty and try to purpose several solutions to it.
\end{abstract}

Keywords: Poverty, Al-Faqir, Al-Miskin.

\begin{abstract}
Abstrak
Kemiskinan sampai detik ini masih menjadi momok bagi setiap individu, tidak terkecuali bagi setiap negara. Masalah kemiskinan merupakan masalah klasik yang muncul bersamaan dengan sejarah manusia itu sendiri. Dalam konteks Indonesia, UUD 1945 sudah mengisyaratkan pemberantasan kemiskinan. Pun, begitu dengan yang diisyaratkan oleh Islam sendiri. Melalui al-Qur'an, Islam dengan tegas mengisyaratkan tentang pemberantasan kemiskinan sebagaimana yang disebutkan dalam banyak kasus, khususnya dalam term al-faqîr dan al-miskîn. Namun dalam kenyataan sehari-hari, ada paradoksi yang nyata antara apa yang dicita-citakan dengan realitasnya. Dalam tulisan singkat ini, penulis akan mencoba kembali mempetakan konsep kemiskinan serta mencoba mengajukan beberapa opsi tentang penanggulangan kemiskinan.
\end{abstract}

Kata Kunci: kemiskinan, al-faqir, al-miskin. 


\section{A. Pendahuluan}

Kemiskinan merupakan salah satu problem pelik yang dihadapi umat manusia. Hasil survey yang dilakukan oleh Sam Mountford yang dirilis pada tanggal 17 Januari 2012 menempatkan isu tentang kemiskinan sebagai masalah krusial dibanding masalah-masalah lainnya. Masalah kemiskinan selalu menjadi penyakit yang menggelayuti setiap negara, tidak terkecuali Indonesia. Kompleksitas dari permasalahan tersebut tidak hanya menyangkut kemiskinan itu sendiri melainkan juga implikasinya yang merasuk ke seluruh aspek kehidupan; tingkat keadaan kesehatan, sarana prasarana pendidikan, korupsi yang semakin merajalela, pengagguran dan PHK yang menjadi ketakutan setiap orang, di mana dampak besar berikutnya adalah terabaikannya kesejahteraan umat atau masyarakat.

Dalam konteks Indonesia, konstitusi negara secara eksplisit menyatakan melalui UUD 1945 pasal 34 bahwa masyarakat miskin menjadi tanggung jawab negara. Pun begitu dengan al-Qur'an-yang menjadi kitab suci mayoritas masyarakat Indonesia_telah memberi pesan-pesan bagaimana menanggulangi kemiskinan. Alih-alih kemiskinan menjadi semakin berkurang, kemiskinan malah semakin bertambah pesat. Peran pemerintah kembali dipertanyakan, paradoksi ayat-ayat normatif al-Qur'an dengan realitas sehari-hari juga tidak terhindarkan.

Realitas kemiskinan tersebut pada akhirnya kembali menarik perhatian guna melahirkan tawaran untuk menanggulangi problem kemiskinan, termasuk al-Qur'an yang berusaha melakukan revolusi bagi masyarakat Arab sebagai salah satu bentuk membangun kesejahteraan masyarakat Arab pada waktu itu. Demikian ini karena al-Qur'an yang terkenal dengan adagiumnya shalihun likulli zaman wa makan harus mampu keluar dari nilai-nilai normatifnya sebagai teks dan bisa mentransformasikan nilai-nilai sosialnya agar solusi al-Qur'an tentang kemiskinan benar-benar dapat diartikulasikan dalam kehidupan seharihari.

Kemiskinan bukanlah masalah taqdir, kemiskinan juga bukan hanya masalah pribadi yang harus diselesaikan oleh masing-masing individu. Bagaimana pandangan al-Qur'an tentang kemiskinan serta bagaimana langkahlangkah yang harus dikedepankan dalam mengentaskan kemiskinan, menjadi fokus tulisan yang akan penulis uraikan. 


\section{B. Tinjauan Umum Tentang Kemiskinan}

Kemiskinan merupakan masalah sosial yang senantiasa hadir di tengahtengah masyarakat dan pada hakikatnya kemiskinan merupakan persoalan klasik yang telah ada sejak umat manusia ada. Kemiskinan merupakan persoalan kompleks dan tampaknya akan terus menjadi persoalan aktual dari masa ke masa yang senantiasa menarik perhatian berbagai kalangan, baik para akademisi maupun para praktisi. Berbagai teori, konsep dan pendekatan dari berbagai multidisipliner keilmuan pun terus menerus dikembangakan oleh para akademisi maupun praktisi untuk menyibak tirai dan mungkin misteri mengenai kemiskinan ini. Kemiskinan bukan saja berurusan dengan persoalan ekonomi belaka, melainkan juga bersifat multidimensional karena dalam kenyataannya juga berurusan dengan persoalan-persoalan non ekonomi, sosial, budaya dan politik. Karena sebab multidimensional tersebut, maka kemiskinan tidak hanya berurusan dengan kesejahteraan sosial (social well-being) saja, akan tetapi lebih dari itu.

Dalam diskursus mengenai kemiskinan ini sendiri, ada tiga pandangan yang berkembang, yaitu konservatisme, liberalisme dan radikalisme. Penganut masing-masing pandangan memiliki cara yang berbeda dalam menjelaskan kemiskinan. Kaum konservatis memandang bahwa kemiskinan bermula dari karakteristik khas orang miskin itu sendiri. Orang menjadi miskin karena tidak mau bekerja keras, boros, tidak mempunyai rencana, kurang memiliki jiwa wiraswasta, fatalis dan tidak ada hasrat untuk berprestasi. Menurut Oscar Lewis, orang-orang miskin adalah kelompok sosial yang mempunyai budaya kemiskinan sendiri yang mencakup psikologis, sosial dan ekonomi. Kaum liberal memandang bahwa manusia sebagai makhluq yang baik tetapi sangat dipengaruhi oleh lingkungan. Budaya kemiskinan hanyalah semacam realistikdan situasional adaptation pada lingkungan yang penuh diskriminsi dan peluang yang sempit. Sedangkankaum radikal mengabaikan budaya kemiskikan, mereka menekankan peranan struktur ekonomi, politik dan sosial dan memandang bahwa manusia adalah makhluk yang koopratif . ${ }^{1}$

${ }^{1}$ Agus Sjafari, Kemiskinan dan Pemberdayaan Kelompok ( Yogyakarta: Graha Ilmu, 2014), 
Implikasi kemiskinan yang melibatkan pandangan-pandangan tersebut menjadikan kemiskinan sebagai sesuatu yang sangat kompleks. Memahami kemiskinanan tentunya tidak hanya dapat dilihat dari satu segi dan satu sudut pandang saja, melainkan harus mampu membacanya dalam kerangka multidisiplineryang komprehensif. Secara sederhana, sebagaimana yang dinyatakan oleh Parsudi Suparlan, kemiskinan dapat didefinisikan sebagai suatu standar tingkat kehidupan yang rendah, yaitu adanya suatu tingkat kekurangan materi pada sejumlah atau segolongan orang dibandingkan dengan standar kehidupan umum yang berlaku dalam masyarakat yang bersangkutan. Standar kehidupan yang rendah ini secara langsung tampak pengaruhnya terhadap tingkat keadaan kesehatan, kehidupan moral, standar pendidikan, tingginya kriminalitas dan lain sebagainya yang muncul dalam masyarakat yang bersangkutan. $^{2}$

Prioritas pengentasan kemiskinan, sebagaimana yang diamanahkan oleh Undang-Undang Dasar 1945 Pasal 34, di mana dalam pasal tersebut secara tegas dinyatakan bahwa fakir miskin dan anak-anak terlantar dipelihara oleh negara. Hampir 70 tahun sudah konstitusi tersebut digagas, namun dalam realitas yang dihadapi, kemiskinan makin meningkat tajam sedangkan upaya untuk menanggulanginya masih jauh dari harapan dan tidak sebanding dengan lonjakan tingkat kemiskinan yang terjadi.

Kemiskinan bahkan menjadi wacana yang paling krusial ketimbangwacana lainnya, misalnya, iklim, terorisme, dan perang. Berdasarkan data yang dirilis Sam Mountford, prosentasi survey adalah sebagai berikut; kemiskinan ekstrim 71\%, lingkungan 64\%, meningkatnya harga pangan dan energy $63 \%$, terorisme dan HAM serta penyebaran penyakit 59\%, ekonomi dunia $58 \%$, dan isu perang $57 \% .^{3}$

Lebih lanjut, suatu penduduk dikategorikan miskin atau tidak miskin berdasarkan Garis Kemiskinan (GK). GK merupakan jumlah rupiah minimum yang dibutuhkan untuk memenuhi kebutuhan pokok minimum makanan dan bukan makanan.Penduduk dikategorikan miskin apabila memiliki rata-rata

2 Parsudi Suparlan, Kemiskinan di Perkotaan: Bacaan Untuk Antropologi Perkotaan (Jakarta: Yayasan Obor Indonesia, 1995), hlm. x.

3 Lihat dalam http://www.antaranews.com/berita/169980/survei-kemiskinan-masalahterbesar-dunia, diakses pada 29 Januari 2017. 
pengeluaran perkapita perbulan dibawah GK. Oleh karena itu, nilai GK berpengaruh terhadap jumlah penduduk miskin pada suatu waktu. Selama periode 2013-2015, Garis Kemiskinan Indonesia mengalami peningkatan setiap tahun, pada tahun 2013 Rp 271.626,- menjadi Rp 330.776,- di tahun $2015 .^{4}$

Dalam konteks masyarakat Indonesia, masalah kemiskinan di Indonesia bukan merupakan masalah baru. Bahkan masalah kemiskinan tersebut telah menjadi topik pembicaraan dan fokus kebijakan pemerintah kolonial Belanda sejak permulaan abad 20 ketika pemerintah kolonial Belanda meluncurkan suatu program anti kemiskinan yang dikenal dengan politik etis. Sesudah indonesia merdeka, masalah kemiskinan tetap menjadi perhatian pemerintah Indonesia, baik dari masa orde lama, orde baru bahkan sampai masa reformasi pada detik ini. Meskipun usaha demi usaha telah dilakukan oleh pemerintah guna menanggulangi kemiskinan, namun masalah tersebut tetap hidup bersama bangsa ini.

Pelaksanaan program penanggulanan kemiskinan telah dilakukan sejak tahun 1998, sampai saat ini secara umum program-program tersebut telah mampu menurunkan angka kemiskinan Indonesia yang berjumlah 47,97 juta atau sekitar 23,43\% pada tahun 1999 menjadi 30,02 Juta atau sekitar 12,49\% pada tahun 2011. Berdasarkan Worldfactbook, BPS dan World Bank, di tingkat dunia penurunan jumlah penduduk miskin di Indonesia termasuk yang tercepat dibandingkan negara lainnya. Tercatat pada rentang tahun 2005 sampai 2009 Indonesia mampu menurunkan laju rata-rata penurunan jumlah penduduk miskin per-tahun sebesar $0,8 \%$ jauh lebih tinggi dibandingkan dengan pencapaian negara lain misalnya Kamboja, Thailand, Cina dan Brasil yang hanya berada di kisaran $0,1 \%$ per-tahun. ${ }^{5}$

Secara umum, persentase penduduk miskin terhadap jumlah seluruh penduduk Indonesia menunjukkan tren menurun secara melambat selama periode 2012-2015. Tingkat penurunan kemiskinan yang hanya mencapai 0,3 persen pada tahun 2015 adalah yang terkecil sepanjang periode empat tahun terakhir. Berdasarkan data yang dihimpun oleh Badan Pusat Statistik Nasional, pemerintah telah berhasil menurunkan jumlah penduduk miskin dari 29,13 juta

${ }^{4}$ Riyadi dkk, Indikator Kesejahteraan Rakyat 2015 (Jakarta: Badan Pusat Statistik BPS, 2015), hlm.122-123.

${ }^{5}$ Daftar Program Pemerintah dalam (http://www.tnp2k.go.id/id/program/program) diakses pada 14 Oktober 2016. 
jiwa atau 11,96 persen pada tahun 2012 menjadi 28,59 juta jiwa atau 11,22 persen pada Maret 2015. Namun demikian, semenjak tahun 2013 jumlah penduduk miskin selalu meningkat setiap tahunnya. Di tahun 2015, jumlah penduduk miskin mengalami peningkatan sebanyak 310 ribu jiwa dari tahun 2014 dan 520 ribu jiwa dari tahun 2013. Peningkatan jumlah penduduk miskin dipicu oleh beberapa faktor, di antaranya terjadi karena meningkatnya harga beberapa komoditas bahan pokok di pasaran dan naiknya harga bahan bakar minyak selama. ${ }^{6}$

Kemiskinan telah memberikan dampak yang luas terhadap kehidupan, bukan hanya kehidupan pribadi mereka yang miskin, tetapi juga bagi orangorang di sekitarnya. Kemiskinan juga disinyalir berimplikasi pada seluruh aspek kehidupan; tingkat kesehatan masyarakat yang terabaikan, aspek kualitas pendidikanyang tidak merata, marginalisasi dan diskriminasi, dalamnya jurang ketimpangan antara yang kaya dan miskin,melambatnya pertumbuhan ekonomi, dan -yang lebih mengkhawatirkan lagi-munculnya perilaku kriminalisasi, misalnya, aksi pencurian, perampokan, penjarahan yang dimotori oleh kemiskinan. Kenyataan ini kembali menguatkan bahwa kemiskinan merupakan penyakit sosial yang harus segera diatasi. ${ }^{7}$

\section{Konsep al-Qur'an Tentang Kemiskinan}

Al-Qur'an berbicara tentang kemiskinan jauh berabad-abad silam sebagai bagian dari misi revolusi masyarakat Arab yang terjebak dalam jurang ketimpangan antara yang kaya dengan yang miskin. Kemiskinan dianggap sebagai petaka, sehingga bagi mereka yang berada dalam garis kemiskinan hanya dijadikan sebagai masyarakat yang marginal dan pantas dijadikan sebagai 'budak' belaka. Bahkan di antara mereka ada yang rela mengubur buah hatinya karena takut menjadi miskin.

Dalam menjelaskan konsep kemiskinan ini, al-Qur'an biasa menggunakan term faqîr dan miskîn. Secara etimologis, lafadz faqîr berasal dari

\footnotetext{
${ }^{6}$ Riyadi, dkk., Indikator Kesejahteraan Rakyat 2015, hlm. 119-120.

7 Wildana Wargadinata, Islam dan Pengentasan Kemiskinan (Malang: UIN Maliki Press, 2011), hlm. 7-9.

${ }^{8}$ Di luar dua term tersebut sebenarnya al-Qur'an memiliki banyak term yang juga digunakan untuk menunjuk orang miskin, misalnya, term da'îf dengan bentuk jamaknya du'afâ, mustad'afûn, arâzil atau arzalûn, al-yatîm atau al-yatâma, al-sâil dan al-mahrûm. Namun dalam penulisan ini, penulis hanya membatasi term yang akan digunakan sebatas konsep faqîr dan miskîn saja.
} 
katafaqura-yafquru-faqârah, yang maknanya lawan dari kaya (al-ghina). Selain faqura, dengan dlammah pada 'ain fi'il-nya, kata faqîr juga dijumpai pada kata kerja faqara-fathah pada 'ain fi'il-nya-yang memiliki makna hafara yang artinya menggali atau melubangi, hazza wa assara fîh yang artinya memotong dan memberi bekas, al-dâhiyah wa al-musîbah al-syadîdah yang artinya malapetaka dan musibah yang dahsyat, seperti yang dijumpai dalam QS. alQiyamah: 25. ${ }^{9}$ Namun Al-Isfahani melontarkan akar etimologis yang berbeda mengenai lafadz faqîr. Di dalam memaknai lafadz faqîr, al-Isfahani berpendapat bahwa lafadz faqîr berasal dari kata al-maksûr al-fiqâr ( ) yang berarti patah tulang punggungnya. Hal tersebut menunjukkan beratnya beban yang dipikul sehingga mematahkan tulang punggungnya. ${ }^{10}$

Di dalam al-Qur'an, lafadz faqîr dengan berbagai derivasinya disebutkan sebanyak 14 kali, yaitu dalam QS. al-Baqarah ayat 268, QS. Ali Imran ayat 181, QS. al-Qasas ayat 24, QS. al-Nisa ayat 6, QS. al-Nisa ayat 135, QS. al-Hajj ayat 28, QS. al-Nur ayat 32, QS. Fathir ayat 15, QS. Muhammad ayat 38, QS. alBaqarah ayat 271, QS. al-Baqarah ayat 273, QS. al-Taubah ayat 60 dan QS. alHasyr ayat $8 .{ }^{11}$

Sedangkan secara terminologis, banyak ulama yang mengemukakan makna terminologis tentang faqîr, salah satunya pendapat Abi Abdullah alQurtubiketika menginterpretasikan QS. Al-Taubah ayat 60:
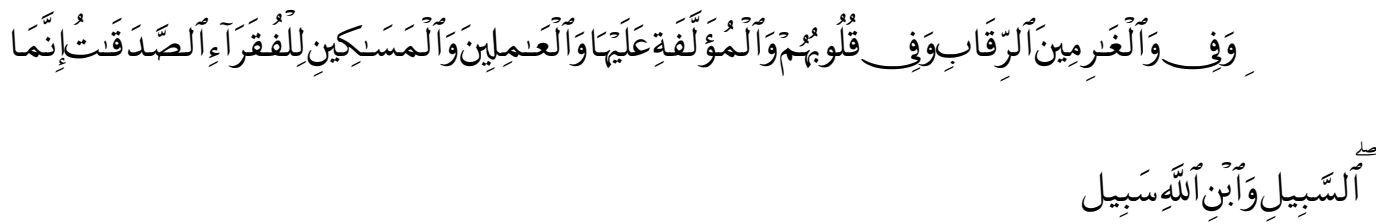

${ }^{9}$ Sahabuddin (ed.), Ensiklopedi al-Qur'an: Kajian Kosakata, Jilid I (Jakarta: Lentera Hati, 2007), hlm. 213.

${ }^{10}$ Ia juga berpendapat bahwa al-faqru yang merupakan bentuk masdar dari faqîr digunakan dalam empat pengertian, yaitu: 1). Kebutuhan primer atau kebutuhan yang mendesak, hal ini terjadi kepada semua makhluk termasuk manusia secara keseluruhan selama mereka masih hidup. Pengertian yang demikian sebagaimana yang tertuang dalam QS. Fathir: 15 2). Menunjukkan tidak adanya penghasilan atau harta simpanan. Hal tersebut sebagaimana yang termuat dalam QS. al-Baqarah: 273, QS. al-Taubah: 60 dan QS. al-Nur: 32 3). Menunjukkan kebutuhan kepada Allah dan menggantungkan diri pada-Nya. Hal tersebut seperti yang tersirat dalam QS. al-Qasas: 24 dan 4). Menunjukkan kefaqiran jiwa. Lihat Al-Ragib al-Isfahani, M u'jam M ufradât Alfâdz al-Qur'ân (Beirut: Dar al-Fikr, t.t), hlm. 379.

${ }^{11}$ M. Fuad Abd al-Baqi, M u'jam M ufahras Li Alfâdz al-Qur'ân (Beirut: Dar al-Fikr, 1992), hlm. 666 
Artinya: "Sesungguhnya zakat-zakat itu, hanyalah untuk orang-orang fakir, orang-orang miskin, pengurus-pengurus zakat, Para mu'allaf yang dibujuk hatinya, untuk (memerdekakan) budak, orang-orang yang berhutang, untuk jalan Allah dan untuk mereka yang sedang dalam perjalanan". (QS. Al-Taubah [09]: 60).

Menurutnya,setidaknya ada 10 pendapat yang menjelaskan tentang makna faqîr. Di antaranya pendapat yang mengemukakan bahwa al-fuqarâ', mufrad kata faqîr, menunjukkan kepada seseorang yang tidak memiliki harta dan tidak mempunyai usaha tetap untuk mencukupi kebutuhannya, seolah-olah ia adalah orang yang sangat menderita karena kefaqiran hidupnya. ${ }^{12}$

Berikutnya term yang banyak digunakan untuk menunjukkan orang yang lemah secara ekonomi adalah term miskîn. Secara etimologis, lafadz miskîn merupakan isim masdar yang berasal dari sakana-yaskunu-sukûn/miskîn. Dilihat dari asalnya, sakana-sukûn, kata ini memiliki makna 'diam', 'tetap' atau reda. Al-Asfihani dan Ibn Mansur mengartikan kata ini sebagai 'tetapnya sesuatu setelah ia bergerak'. Selain arti tersebut, kata sakana-sukûn juga bisa diartikan sebagai 'tempat tinggal'. ${ }^{13}$

Term miskîndengan bentuk jamaknya masâkîn yang bermakna orang miskin, di dalam al-Qur'an, lafadz ini berjumlah 23 dengan perincian sebagai berikut, yaitu QS. al-Baqarah ayat 184, QS. al-Qalam ayat 24, QS. al-Mujadalah ayat 4, QS. al-Insan ayat 8, QS. al-Balad ayat 16, QS. al-Maidah ayat 89 dan 95, QS. al-Kahfi ayat 79, QS. al-Haqqaq ayat 34, QS. al-Mudassir ayat 44, QS. alFajr ayat 18, QS. al-Ma'un ayat 3, QS. al-Isra ayat 26, QS. al-Rum ayat 38, QS. al-Baqarah ayat 83, 177 dan 215, QS. al-Nisa ayat 36, QS. al-Anfal ayat 41, QS. al-Taubah ayat 60, QS. al-Nur ayat 22 dan QS. al-Hasyr ayat 7. ${ }^{14}$

Jika dilihat dari makna aslinya yang berarti 'diam', maka kata miskîndapat ditarik arti secara istilah, yaitu orang yang tidak dapat memperoleh sesuatu untuk memenuhi kebutuhan hidupnya dan diamnya itulah yang menyebabkan kemiskinan. Orang tersebut dapat memperoleh sesuatu dikarenakan ia tidak bergerak dan tidak ada kemauan atau peluang untuk bergerak, sebagaimana yang diisyaratkan dalam QS. al-Kahfi ayat 79:

${ }^{12}$ Abi Abdullah al- Qurtubi,Tafsir al-Qurtubi, Jilid VIII, terj. Budi Rosyadi (Jakarta: Pustaka Azzam, 2008), hlm. 407.

${ }^{13}$ Sahabuddin, Ensiklopedi al-Q ur'an: Kajian Kosakata, Jilid I, hlm. 610.

${ }^{14}$ M. Fuad Abd al-Baqi, Mu'jam M ufahras Li Alfâdz al-Q ur'ân, hlm. 449. 


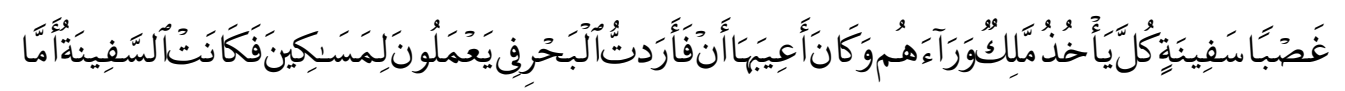

Adapun bahtera itu adalah kepunyaan orang-orang miskin yang bekerja di laut, dan aku bertujuan merusak bahtera itu, karena di hadapan mereka ada seorang raja yang merampas tiap-tiap bahtera. (QS. al-Kahfi: 79)

Kata miskin juga dapat diartikan dengan orang yang tidak memiliki sesuatu, atau memiliki sesuatu namun tidak mencukupinya, atau orang yang dibuat diam oleh kefakiran serta dapat pula diartikan dengan orang yang hina dan lemah. ${ }^{15}$ Selain itu, kata miskin juga dapat diartikan sebagai orang yang tidak memiliki apa-apa (المسكين الذي لاشيء له), dan ada juga yang berpendapat bahwa miskin adalah orang yang tidak memiliki sesuatu yang dapat mencukupi kebutuhan hidupnya (وقيل الذي لاشيء له يكفي عياله).

Selain definisi terminologis tersebut, para pakar agama juga berbeda pendapat dalam menetapkan tolok ukur kemiskinan dan kefakiran. Secara langsung, tidak ada informasi al-Qur' an maupun hadis dalam menetapkan angka tertentu lagi pasti sebagai ukuran kemiskinan. Al-Qur'an hanya menegaskan perintah untuk menyantuni orang fakir dan miskin, larangan menganiaya mereka, larangan memarginalkan dan mendiskreditkan mereka, larangan menumpuk harta, dan lain sebagainya. ${ }^{17}$

\section{Langkah-Langkah Pengentasan Kemiskinan dalam Upaya Membangun Kesejahteraan Umat}

Perlu disadari, bahwa harta merupakan pit fall seluruh lapisan masyarakat, terkecuali orang-orang tertentu yang dijamin kema'sumannya. Kemiskinan tidak lahir begitu saja, melainkan ada latar belakang dan penyebabnya. Walaupun para ahli ilmu-ilmu sosial sependapat bahwa sebab utama yang melahirkan kemiskinan adalah sistem ekonomi yang berlaku dalam masyarakat yang bersangkutan, tetapi kemiskinan itu sendiri bukanlah suatu gejala terwujud semata-mata hanya karena sistem ekonomi. ${ }^{18}$

\footnotetext{
${ }^{15}$ Majd al-Dîn al-Fayruz Âbadi, Qâmus al-Muhît (Beirut: Dar al-Fikr al-Tiba'ah wa al-Nasyr al-Tawzi, 1999), hlm. 1087.

${ }^{16}$ Ibn Mansûr, Lisân al-Arab, Juz III (Beirut: Dar Ilmiyah, 2009), hlm. 260.

17 M. Nur Kholis Setiawan, Pribumisasi al-Qur'an; Tafsir Berwawasan Keindonesiaan (Yogyakarta: Kaukaba, 2012), hlm. 159.

18 Sa'ad Ibrahim,Kemiskinan dalam Perspektif al-Qur'an (Malang: UIN Malang Press, 2007), hlm. 52.
} 
Sebelum diurai langkah-langkah pengentasan kemiskinan, terlebih dahulu harus diketahui jenis-jenis kemiskinan. Secara umum ada tiga gejala kemiskinan, yaitu: a) kemiskinan natural; b) kemiskinan kultural; dan c) kemiskinan struktural. Kemiskinan natural adalah kemiskinan yang dialami oleh seseorang sejak lahir, dikarenakan terlahir dari keluarga miskin, dan hidup dalam lingkungan miskin. Kemiskinan kultural adalah kemiskinan yang disebabkan oleh faktor kultural, seperti gaya hidup malas bekerja sehingga terjerembab dalam jurang kemiskinan. Sedangkan kemiskinan struktural adalah kemiskinan yang disebabkan oleh adanya sistem atau struktur yang mencegah sebagian besar orang untuk menjadi kuat, sejahtera, bahkan kaya. ${ }^{19}$

Melihat fenomena tersebut, tawaranpenulis, langkah-langkah penanggulangan kemiskinan bisa dijalankan melalui tiga hal, yaitu:

1. Rekonstruksi Teologi Kemiskinan.

"Kemiskinan yang disandang oleh orang miskin dan kekayaan yang dimiliki oleh orang kaya merupakan kehendak dan takdir Tuhan. Jika Tuhan berkehendak, Dia bisa menjadikan semua manusia menjadi Qarun. Tetapi Tuhan sengaja membatasi rezeki untuk orang yang dikehendakinya, untuk menguji mereka". Ungkapan tersebut merupakan bentuk pembelaan yang sering dilontarkan oleh orang miskin. Hal tersebut disebabkan karena keyakinan mereka bahwa kemiskinan adalah takdir dan kuasa Tuhan, sebuah keyakinan fatalistik.

Rekonstruksi teologis yang penulis maksud, adalah bagaimana merubah cara pandang dan logika berpikir tentang kemiskinan. Kemiskinan lahir bukan semata-matadisebabkan oleh faktor takdir, melainkan lebih kepada penganiayaan terhadap diri sendiri. Hal ini senada dengan arti etimologis 'miskin' itu sendiri, yaitu 'diam atau tidak bergerak'. Dari sini diperoleh kesan bahwa faktor utama penyebab kemiskinan adalah sikap

${ }^{19}$ Suroyo, dkk., Agama dan Kepercayaan membawa Pembaruan (Yogyakarta: Kanisius, 2006), hlm. 97. 
berdiam diri, enggan, atau tidak mau bergerak atau berusaha, dan keengganan berusaha adalah bentuk penganiayaan terhadap diri sendiri. ${ }^{20}$

Padahal Allah swt. telah menjamin rizki setiap orang di muka bumi. Kewajiban setiap individu adalah berusaha mencarinya dan keluar dari rongrongan kemiskinan. Allah berfirman dalam QS. Hud ayat 6 dan QS. AlDzariyat ayat 58:

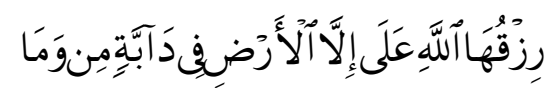

Artinya: " dan tidak ada suatu binatang melata pun di bumi melainkan Allah-lah yang memberi rezkinya..." . (QS. Hud [11]: 6).

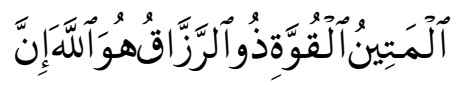

Artinya: "Sesungguhnya Allah Dialah Maha pemberi rezki yang mempunyai kekuatan lagi sangat kokoh." (QS. Al-Dzariyat [51]: 58).

Maka tidak heran jika Rasulullah pernah berdo'a sebagaimana yang terekam dalam salah satu hadisnya: "Ya Allah, aku berlindung kepadamu dari kekufuran dan kefakiran". (HR. Abu Daud). Nabi saw. mengucapkan do'a tersebut berarti mewajibkan setiap individu untuk keluar dari kemiskinan. Kemiskinan itu sama celanya dengan kekufuran, dan karena setiap individu harus memerangi kekufuran, berarti juga harus memerangi kemiskinan.

Manusia memiliki kuasa atas dirinya sendiri, tidak terkecuali kuasa atas dirinya keluar dari kemiskinan dan melakukan perubahan sosial. Ayat yang sering dirujuk kaitannya dengan hal tersebut adalah QS. Al-Ra'd ayat 11:

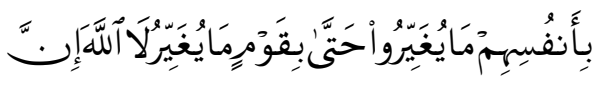

Artinya: "Sesungguhnya Allah tidak merobah Keadaan sesuatu kaum sehingga mereka merubah keadaan yang ada pada diri mereka sendiri..." (QS. Al-Ra'd [13]: 11)

${ }^{20}$ M. Nur Kholis Setiawan, Pribumisasi al-Qur'an; Tafsir Berwawasan Keindonesiaan, hlm. 
Ayat ini berbicara tentang konsep perubahan masyarakat, yang menurut Quraish Shihab, ditafsirkan sebagai sebuah proses perubahan yang memberi posisi manusia menjadi pelaku perubahan. Dalam posisinya sebagai pelaku perubahan, di samping manusia bergerak sebagai wujud personal, juga bagian dari komunitas dan masyarakat. ${ }^{21}$ Berdasarkan ayat tersebut, betapa Allah menegaskan bahwa perubahan sosial, baik personal maupun masyarakat, juga lahir dari kuasa diri.

Dalam konteks kemiskinan, rekontruksi teologis yang dimaksud penulis adalah melakukan perubahan sosial. Perubahan sosial harus dimulai dari perubahan individu yang meliputi pola pikir, motivasi, pandangan hidup, dan segala aspek terkait lainnya. Jika pola pikir masyarakat miskin meniscayakan bahwa miskin adalah takdir Allah, maka keluar dari cengkeraman kemiskinan adalah juga takdir Allah.

2. Membangun Kesadaran Kolektif Pemberantasan Kemiskinan.

Konsep yang sangat mendasar dalam ajaran Islam adalah bahwa setiap orang harus memerangi kemiskinan dengan cara berusaha dan bekerja. Masalahnya sekarang, apa dosa orang-orang yang lemah yang sudah tidak mampu lagi bekerja? Apa kesalahan para janda yang ditinggal mati suaminya, sementara mereka tidak memiliki simpanan harta yang cukup? Apa kesalahan para orang tua jompo? Apa kesalahan orang-orang yang memiliki penyakit kronis?

Fenomena tersebut menegaskan bahwakemiskinan bukan hanya menjadi beban pribadi, tetapi juga menjadi beban dan tanggung jawab bersama untuk menanggulanginya. Dalam konteks ini, hemat penulis, sangat diperlukan adanya kesadaran bersama yang harus dibangun guna menanggulangi kemiskinan, baik kesadaran tersebut sifatnya personal atau individu yang dialakukan oleh masyarakat, maupun kesadaran penuh yang menjadi tanggung jawab pemerintah melalui kebijakannya.

Pertama, kesadaran personal. Kesadaran personal atau individu dalam upaya mengentaskan kemiskinan merupakan salah satu instrumen yang tidak kalah penting. Bahkan kesadaran personal tersebut telah digagas pula oleh al-

${ }^{21}$ M. Quraish Shihab, Secerca Cahaya Ilahi (Bandung: Mizan, 2000), hlm. 242. 
Qur'an. Cukup banyak ayat al-Qur'an yang mengupayakan pembentukan pribadi luhur, dermawan, dan berani berkorban. Hal itu bisa tumbuh, berangkat dari kesadaran bahwa harta bukan tujuan, melainkan sebatas sarana untuk bersedekah dan berbuat baik kepada orang lain.
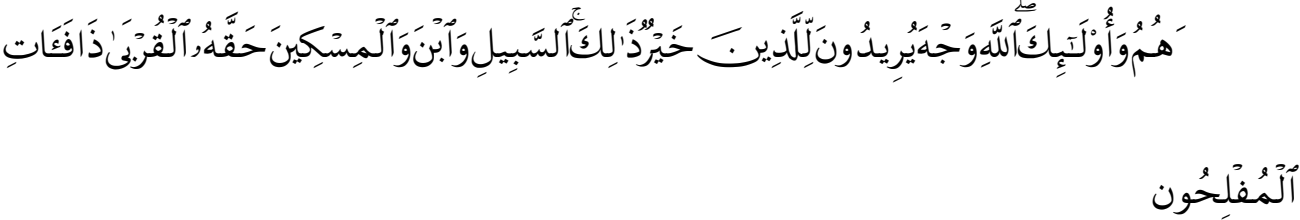

Artinya: "Maka berikanlah kepada kerabat yang terdekat akan haknya, demikian (pula) kepada fakir miskin dan orang-orang yang dalam perjalanan. Itulah yang lebih baik bagi orang-orang yang mencari keridhaan Allah; dan mereka Itulah orang-orang beruntung." (QS. Al-Rum [30]: 38).

Dalam ayat yang lain, betapa Allah menjanjikan balasan yang sangat besar kepada setiap individu yang mendermakan hartanya kepada sesama, khususnya kepada masyarakat yang hidup dalam kemiskinan. Allah menegaskan dalam QS. Al-Baqarah ayat 245:

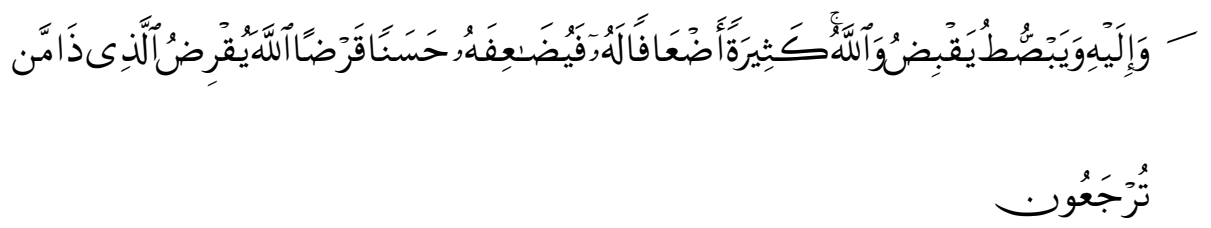

Artinya: "siapakah yang mau memberi pinjaman kepada Allah, pinjaman yang baik, maka Allah akan meperlipat gandakan pembayaran kepadanya dengan lipat ganda yang banyak. dan Allah menyempitkan dan melapangkan (rezki) dan kepada-Nya-lah kamu dikembalikan." (QS. Al-Baqarah [02]: 245).

Secara etimologis, lafadz qardan dalam ayat tersebut bermakna 'pinjaman' suka rela yang didermakan seseorang kepada orang lain. Sedangkan makna yang dimaksud dalam ayat tersebut, menurut Ibn Katsir, sebagaimana pendapat yang bersumber dari Umar dan beberapa ulama lainnya, adalah infak di jalan Allah. Selain itu ada pula yang mengatakan bahwa yang dimaksud ayat tersebut adalah pemberian kepada keluarga. ${ }^{22}$

${ }^{22}$ Ibn Katsir, Lubab al-Tafsir min Ibn Katsir, Jilid. I, terj. Abd. Ghaffar (Jakarta: Pustaka Imam Syafi'i, 2008), hlm. 498. 
Dengan demikian, maksud ayat tersebut adalah barang siapa yang membantu sesama, baik orang lain maupun keluarga, maka Allah akan melipatgandakan pemberian tersebut sebagaimana yang ditegaskan dalam QS. Al-Baqarah ayat 26.

Islam—sebagai agama—sudahseharusnya memperhatikan aspek moral yang luhur, dan tidak mencukupkan pada hak-hak seperti yang diatur dalam undang-undang dan dilaksanakan oleh pemerintah. Karena aspek legal dan pelaksanaan oleh pemerintahbukanlah satu-satunya sarana untuk merealisasikan solidaritas antar manusia. Islam bukan hanya memperhatikan moralitas yang luhur, tapi lebih dari itu, Islam mendorong terbentuknya pribadi yang saleh. ${ }^{23}$

Kedua, peran pemerintahan. Telah penulis singgung sebelumnya, aspek pemerintahan bukan merupakan sarana utama. Namun demikian, peran pemerintah sangat menentukan, baik dalam membuat masyarakat menjadi miskin, maupun keluar dari kemiskinan. Kebijakan yang kurang tepat dan ketidakberpihakan terhadap masyarakat miskin akan menciptakan kemiskinan yang semakin akut.Indonesia sebagai negara penganut konsep walfare state (negara sejahtera) seharusnya sudah mampu melahirkan kebijakan-kebijakan yang dapat mensejahterakan rakyatnya, namun dalam realitasnya hal ini belum dapat dilaksanakan secara maksimal.

Selama ini beberapa kebijakan yang notabene diharapkan mampu mengentaskan kemiskinan masih banyak yang bersifak konsumtif. Sebut saja bantuan beras untuk rakyat miskin (raskin), Bantuan Langsung Tunai (BLT), dan subsidi lainnya yang kurang tepat sasaran, seperti BBM dan listrik, di mana anggaran keduanya pada RAPBN-P 2014 mengalami pembekakan sampai 110,7 triliun.Padahal pengguna subsidi keduanya kebanyakan dinikmati masyarakat yang tidak tergolong 'miskin'.

Namun di sisi yang berbeda, sebenarnya sudah ada program pemerintah yang bersifat produktif. Misalnya kebijakan program PNPM Mandiri Pedesaan dengan total anggaran Rp. 10,3 triliun pada 2013, Kredit

${ }^{23}$ Yusuf al- Qaradlawi, Teologi Kemiskinan; Dokrin Dasar dan Solusi Islam atas Problem Kemiskinan, ter. Maimun Syamsuddin (Yogyakarta: Mitra Pustaka, 2002), hlm. 268. 
Usaha Rakyat (KUR), dan lain sebagainya. Hanya saja dalam realitasnya realisasi program tersebut belumlah maksimal, bahkan dengan adanya anggaran yang begitu besar-sedangkan tindakan pengawasan tidak berjalan dengan baik-program-program tersebut bisa jadi akan dijadikan lumbung 'pencurian uang rakyat' oleh para koruptor.

Namun demikian, penulis masih sangat berharap, komitmen pemerintah yang besar dalam menanggulangi kemiskinan ini dapat menghasilkan pertumbuhan yang inklusif; pertumbuhan ekonomi yang berpihak pada rakyat miskin, dibukanya sektor lapangan kerja seluas-luasnya agar angka pengangguran dapat ditekan sekecil mungkin, membangun dan menyempurnakan sistem perlindungan sosial bagi masyarakat miskin, perbaikan sektor sarana dan prasarana pendidikan sehingga dapat melahirkan SDM yang lebih baik, dan lain sebagainya sehingga mampu menciptakan pertumbuhan untuk semua secara adil dan merata.

Dalam pengentasan kemiskinan-baik pemerintah maupun masyarakat secara personal-harus menggerakkan segala kemampuan, berusaha memenuhi kebutuhan serta memanfaatkan potensi yang dimiliki, baik potensi basyariyah (kemanusiaan) atau potensi material, untuk selalu berusaha menghancurkan 'taring-taring' kemiskinan dan menjinakkan keganasannya. Dengan semakin bertambahnya produksi dan semakin meningkatnya pemasukan secara umum akan berdampak positif dan efektif dalam memerangi fenomena kemiskinan. ${ }^{24}$

3. Membangun Etos Kerja Individu

Tawaran yang terakhir dalam memberantas kemiskinan adalah dengan cara membangun etos kerja. Berbeda dengan dugaan sementara orang yang beranggapan bahwa Islam kurang menyambut baik kehadiran harta. Pada hakikatnya, pandangan Islam terhadap harta sangat positif. Manusia diperintahkan Allah swt. untuk mencari rezeki bukan hanya untuk mencukupi kebutuhan hidupnya, tetapi juga untuk mencari apa yang diistilahkan dengan fadlullah, yang secara harfiah berarti 'kelebihan' yang bersumber dari Allah

24 Yusuf al- Qaradlawi, Teologi Kemiskinan; Dokrin Dasar dan Solusi Islam atas Problem Kemiskinan, hlm. 106. 
swt. $^{25}$ Kelebihan yang bersumber dari Allah tersebut hanya bisa digapai melalui faktor etos kerja yang dimiliki seseorang.

Etos kerja pada hakikatnya merupakan bagian dari konsep Islam tentang manusia karena etos kerja adalah bagian dari proses eksistensi diri manusia dalam lapangan kehidupannya yang amat luas dan kompleks. Menurut Musa Asy'ari, etos kerja adalah rajutan nilai-nilai yang membentuk kepribadian seseorang dalam bekerja, yang kemudian membentuk semangat yang membedakannya, antara yang satu dengan yang lainnya. Etos kerja dalam Islam dengan demikian merupakan refleksi pribadi seseorang yang bekerja dengan bertumpu pada kemampuan konseptual yang bersifat kreatif dan inovatif. ${ }^{26}$

Salah satu ayat yang mendorong setiap individu untuk membangun etos kerja adalah QS. Al-Jumu'ah ayat 10:

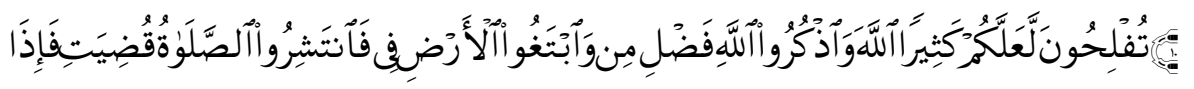

Artinya: " apabila telah ditunaikan shalat, Maka bertebaranlah kamu di muka bumi; dan carilah karunia Allah dan ingatlah Allah banyakbanyak supaya kamu beruntung." (QS. Al-Jumu'ah [62]: 10).

Semangat etos kerja ini juga dikaitkan dengan konsep Islam tentang perubahan sosial. Sejarah telah mencatat bahwa perubahas sosial, termasuk di dalamnya juga perubahan ekonomi, merupakan misi utama sejak pertama kali al-Qur'an diturunkan kepada Nabi Muhammad saw. empat belas abad silam. Bahkan Nabi sendiri sejak muda sudah menjadi seorang pembisnis dan pengembala sebagai bentuk memberikan teladan kepada para sahabat. Maka provokasi Nabi melalui hadisnya terhadap masyarakat Arab pada waktu itu, merupakan hal yang sangat realistis. Nabi bersabda:

${ }^{25}$ M. Quraish Shihab, Membumikan al-Qur'an (Bandung: Mizan, 1995), hlm. 165.

${ }^{26}$ Musya Asy'ari, "Etos Kerja Islam sebagai landasan Pengembangan Jiwa Kewirausahaan” dalam Moh. Ali Aziz (ed.), Dakwah Pemberdayaan Masyarakat: Paradigma Aksi Metodologi (Yogyakarta: LKiS, 2005), hlm. 35-36. 
"Tidak ada satu makananpun yang dimakan seseorang yang lebih baik dari hasil kerja tangannya sendiri. Dan Nabi Daud as. makan dari tangannya sendiri.(HR. Imam Bukhari).

Etos kerja merupakan senjata utama dalam memerangi kemiskinan. Ia adalah sarana pertama untuk menghasilkan harta benda dan membangun kesejahteraan masyarakat.Dalam etoskerja terkandung "spirit" atau semangat untuk mengubah sesuatu menjadi jauh lebih baik. Dengan etos kerja pula, kemiskinan dapat diperangi sehingga seseorang dapat dan mampu keluar dari jurang kemiskinan.

\section{E. Penutup}

Melonjaknya data kemiskinan yang dirilis oleh Badan Pusat Statistik (BPS)—di mana data kemiskinan meningkat 11,47 persen atau meningkat 480 ribu orang-merupakan bukti bahwa kemiskinan masih mengrogoti bangsa Indonesia. Kemiskinan sebagai penyakit sosial tentu memerlukan beragam tindakan dan solusi bersama guna menekan dan mengentaskan angka kemiskinan tersebut. Hal ini mengingat bahwa kemiskinan tidak hanya berdampak pada pribadi yang bersangkutan, melainkan juga memiliki efek sistemik terhadap kehidupan sosial lainnya.

Melalui tulisan ini, penulis ingin menegaskan bahwa kemiskinan bukanlah sesuatu yang memiliki sifat given, taqdir, melainkan lebih merupakan hasil konstruksi sosial, sehingga perlu adanya rekonstruksi teologis dalam memandang kemiskinan. Selain itu kemiskinan tidak hanya menjadi tanggung jawab pribadi bagi yang bersangkutan, oleh sebab itu, membangun kesadaran bersama, baik personal maupun pemerintah adalah hal yang niscaya. Namun demikian, ikhtiyar dan etos kerja menjadi modal utama untuk melawan kemiskinan tersebut. Melalui langkah-langkah pengentasan kemiskinan tersebut, hemat penulis, merupakan satu instrumen besar dalam membangun kesejahteraan umat. Wallahu a'lam.

\section{DAFTAR PUSTAKA}

Âbadi, Majd al-Dîn al-Fayruz. Qâmus al-Muhît. Beirut: Dar al-Fikr al-Tiba'ah wa alNasyr al-Tawzi, 1999. 
Asfahani, Al-Ragib al-. Mu'jam Mufradat Alfadz al-Qur'an. Beirut: Dar al-Fikr, 2008.

Asy'ari, Musya. "Etos Kerja Islam Sebagai Landasan Pengembangan Jiwa Kewirausahaan”. Moh. Ali Aziz, (ed.). Dakwah Pemberdayaan Masyarakat: Paradigma Aksi Metodologi. Yogyakarta: LKiS, 2005.

Baqi, M. Fuad Abd al-. Mu'jam M ufahras Li Alfâdz al-Qur'ân. Beirut: Dar al-Fikr, 1992.

Ibrahim, Sa'ad. Kemiskinan dalam Perspektif al-Qur'an. Malang: UIN Malang Press, 2007.

Katsir, Ibn. Lubab al-Tafsir min Ibn Katsir. Jilid. I. terj. Abd. Ghaffar. Jakarta: Pustaka Imam Syafi'i, 2008.

Mansûr, Ibn. Lisân al-Arab. Juz III. Beirut: Dar Ilmiyah, 2009.

Qaradlawi, Yusuf al-. Teologi Kemiskinan; Dokrin Dasar dan Solusi Islam atas Problem Kemiskinan. terj. Maimun Syamsuddin. Yogyakarta: Mitra Pustaka, 2002.

Qurtubi, Abi Abdullah al-. Tafsir al-Qurtubi. Jilid VIII. terj. Budi Rosyadi. Jakarta: Pustaka Azzam, 2008.

Riyadi. dkk,. Indikator Kesejahteraan Rakyat 2015. Jakarta: Badan Pusat Statistik BPS, 2015.

Sahabuddin. Ensiklopedi al-Qur'an; Kajian Kosa Kata. Jilid I. Jakarta: Lentera Hati, 2007.

Setiawan, M. Nur Kholis. Pribumisasi al-Qur'an; Tafsir Berwawasan Keindonesiaan. Yogyakarta: Kaukaba, 2012.

Shihab, M. Quraish. Membumikan al-Q ur'an. Bandung: Mizan, 1995. -Secerca Cahaya Ilahi. Bandung: Mizan, 2000.

Sjafari, Agus. Kemiskinan dan Pemberdayaan Kelompok. Yogyakarta: Graha Ilmu, 2014.

Suparlan, Parsudi. Kemiskinan di Perkotaan: Bacaan Untuk Antropologi Perkotaan. Jakarta: Yayasan Obor Indonesia, 1995.

Suroyo, dkk.Agama dan Kepercayaan Membawa Pembaruan. Yogyakarta: Kanisius, 2006.

Wargadinata, Wildana. Islam dan Pengentasan Kemiskinan. Malang: UIN Maliki Press, 2011.

\section{Sumber Internet:}

http://www.antaranews.com/berita/169980/survei-kemiskinan-masalah-terbesardunia.

http://www.tnp2k.go.id/id/program/program. 